\title{
Distribution of Direct Teaching Plants and Teaching Manpower Resources in Era of Economic Recession for Upper Basic Education in Rivers State, Nigeria
}

\author{
Dr Ledego, F.S, Dr. Ukaigwe, P. C \\ Department of Educational Management, University of Porthar court Rivers State, Nigeria
}

*Corresponding Author: Dr. Agabi, G. O, Department of Educational Management, University of Porthar court Rivers State, Nigeria

\begin{abstract}
This study investigated the distribution of direct teaching plants, teaching manpower resources and their qualities in the era of economic recession, for public Upper Basic Education delivery in Rivers State, Nigeria. It is a descriptive survey that involved the administration of a validated 166-item observation schedule titled: "School Resources distribution Survey"' on a random sampled population of 89 school Heads (32 urban and 57 rural), which made up 50\% each, of the category of schools in 12 sampled local government area of Rivers State. The data gathered were analysed using mean, mean set, percentages and graphical presentations to address four research questions. The results revealed that the distribution of direct teaching plants, in schools located both in urban and rural areas were not only inadequate, but the conditions of the existing ones were generally poor. Teaching manpower distribution were found inadequate in the schools in all subjects, worsened by the economic recession.. Although the schools have moderately good quality teachers, the available ones were over-utilized. Consequently, it was concluded that the present status of facilities, teachers' distribution and economic recession cannot ensure the delivery of quality upper basic education. It was then recommended that the Ministry of Education should establish and equip educational resource centres, workshops in selected schools, financially supported, for the delivery of quality education against the influence of economic recession.
\end{abstract}

Keywords: Direct Teaching Plants, Distribution, era of Economic Recession, Upper Basic Education Delivery.

\section{INTRODUCTION}

Educational resources are those materials one uses to assist in the achievement of predetermined educational goals and objectives with a view to ensure socio-political and economic survival of a nation. Practically, educational resources can be seen to include physical facilities, materials, funds, human beings and drawn academic programmes. In functional term, these resources can be classified direct and indirect teaching plants, human and financial resources. It is the human that would always harness the other resources to effect production. A critical study of the physical and material resources revealed the sub-divisions of these resources into direct and indirect teaching plants. Observed practical cognitive and psychomotor designed school activities classified teaching plants direct and indirect. In functional terms and designs direct teaching plants include; school buildings such as classrooms, science laboratories and libraries. The entire school ground, recreational facilities and offices indirect teaching plants. While instructional materials such as stationeries, educational plans, objectives, planned programmes and the prescribed methodologies are the material resources. The teaching and non-teaching staff, skills, knowledge and ability are the human resources. Finally, all that are made up of monetary input into the educational system directed towards the achievement of educational objectives he grouped under financial resources.

Maduagwu and Nwogu, (2006:4), said, "The quality of education delivery in a school setting is the product of the scope of distributed educational resources and their qualities. It is the availability of these resources that can guarantee the achievement of a maximum dispensation of activities in the school system". This implies that the extent, to which quality education delivery succeeds, depends strictly on the quantity and quality of the resources, engaged in the educating process and the effectiveness with which these resources were distributed to the various activities, in the schools. 
Commenting on the present condition of direct teaching plants in secondary schools in Nigeria, nine years today and the persistent economic instability in the midst of plenty (Rivers State), Marinoho (2009:17) decried, "Schools in Nigeria have four major problems which are, broken walls and roof of the classrooms, lack of libraries, books lacking local content and obsolete laboratories equipment." In these respects, the quantity and quality of educational resources distribution in the nascent education system (UBE) should be a determined, conscious and deliberate acts, focused at periodically projected purchase of resources, with the determination to deliver educational services in order to survive the influence of economic recession. This is because education is the key instrument that directs, designs production in developmental strikes. According to Lawrence (2018), development is the improvement of the instrument of production for which education stands.

Upper Basic Education is the same as Junior Secondary School (JSS 1-3).Some scholars call it Basic 7-9. It is an integrated education that prepares one for Senior Secondary School education where one narrowed his or her scope of studies into specialized subject areas in preparation for tertiary levels of education. This work becomes relevant because education is an instrument that enhances production and development which cannot be fashioned except the availability of educational resources is guaranteed.

\subsection{Statement of the Problem}

The nascent Universal Basic Education (UBE) scheme is Nigeria's response to a global call to nations to eradicate illiteracy by providing citizens with quality basic education. This ambitious programme requires that relevant resources be adequately and rationally distributed. However, no one appears sure of how these resources have been adequately distributed and the condition of the available resources now that the nation is in the heat of economic recession. These puzzles provided the stimulation for this study and hence constitute the problem of this study.

\subsection{Objectives of the Study}

That educational resources are always in intensive use, exposed to natural phenomenon of use and wares, demanding regular survey, purposed this study to determine the adequacy of direct teaching plants, their condition and the adequacy of teaching manpower, distribution in upper basic level of the educational system and their quality in a nation experiencing persisting economic recession.

\subsection{Research Questions}

The following research questions were addressed in the study:

1. How adequate in this economic recession (ER), is the distribution of physical direct teaching plants for public upper basic education delivery in Rivers State of Nigeria?

2. What are the conditions of these direct teaching plants in urban and rural areas of Rivers State?

3. How adequate is the distribution of teaching manpower resources in this for public upper basic education delivery in urban and rural areas of Rivers State?

4. What is the quality of teaching manpower resources for public upper basic education delivery in urban and rural areas of Rivers State?

\subsection{Concept Clarification}

Excluding human and financial resources, direct teaching plants are those designed physical features that accommodate or house teaching learning activities, including the graphic and instructional materials that assist the understanding of concepts. Indirect teaching plants are those not designed to accommodate teaching learning activities but are essential for educational practices. Emetaron (1999:54) identified educational resources as "human beings, funds, physical facilities and programmes".

Nwogu (2009:129) in his contribution on distribution positioned when he said, "in most formal organizations, subjective or political criteria predominates issues of resources distribution rather than objective criteria, subjective criteria causes imbalance in resources distribution and may even lead to wastage of resources". Charles, Obiora and Omekwu (2006), Nwaeke (2006) and Okeke (2007) maintained that facilities in public schools in Nigeria since the inception of UBE had generally been 
inadequate, beside the fact that their conditions are deplorable due to use and wares. This suggests it will be worst in the era of economic recession. This is pointing to the adoption of a standard model for resources distribution to maintain equitable distribution of educational resources since UBE programme emphasizes social demand for education which has led to greater demands for education. It is on this ground that the Federal High Court (2017) held that failure by any government to fund primary and junior secondary education would constitute breach of the constitution. This has ensured the practice of education on its macro-scale. Macro-scale education is a form of education which found expression in its aim to eradicate illiteracy and ignorance for all. The need to achieve the above in economic recession informed this study.

Economic recession refers to a situation where capital structures are in place, but there is a decline in the means to sustain recurrent expenditures (payment of salaries and wages, repairs ect.) that keep those structures working because of sudden change in taste and price. In the educational sector, it is a time parents withdraw their children from private to public schools; in some cases students have extra years or total drop out of school because of inability to pay school fees.(Barisua,2017, Igbudu \& Ipalibo, 2017,and Lawrence, 2018,)

\subsection{Theoretical Framework}

This research has its theoretical framework founded on resources distribution theory propounded by Babalola (2000). The theory stated that optimum distribution of resources is achieved by looking into the price system in which resources move from less profitable to more profitable uses and from less important to more important uses. The prize system being critically weighed, directs allocation of resources to areas which are relevant to the need of the society, despite the competing demands for same resources in other areas, with the assertions that the fore-gone alternatives would not cause damages to the economy. For instance, the training of teachers and medical doctors cannot be avoided despite the capital involved in their procurement. It is also stated that production techniques will make the greatest use of plentiful resources when available or make the less use of relatively scarce resources (era of scarcity) to achieve desired result as if resources are in abundance (eg a tailor in his production of clothes will waste cloth where provided piece has extra but economical and tactical when the provided piece of cloth is not enough to achieve the same result). In education, the prizes are the products and the forgone alternatives, while engaging in educational practices to enhance socio-political and economic development. These- prices include time, energy, strategies against financial provision shortfalls etc. Involvements in the process to achieve and engage the calibre of human (teachers etc) resources needed for the production of goods and services in economic recession, the issue of planning, procurement of resources and their distribution while implementing educational programmes or project make the theory relevant in an era of economic recession.

\section{Methodology}

This is a descriptive survey design study. The population consists of the 268 public upper basic [Basic 7-9(JS 1-3)] schools in Rivers State and the 268 Head teachers of these schools, as respondents. A total population of 89 upper basic schools spread across 12 sampled Local Government Areas (LGAs) of Rivers State were used for the study. Stratified random sampling technique based on urban - rural dichotomy was applied to sample LGAs and schools for the study. Firstly, 50\% of LGAs in each category were randomly sampled, giving a total of 12 out of 23 LGAs. Secondly, $50 \%$ of schools in each of the sampled LGAs were randomly sampled, giving a total of 89 schools (32 in urban areas and 57 in rural areas). All the 89 head teachers of these schools were used as research assistants for the study. The instrument for this study is a 166 item observation schedule (survey inventory) titled "School direct plants, distribution Survey", which is in three parts. Section A is a demographic survey Section B is the school facilities need survey inventory and Section C the teaching manpower survey inventory. The instrument was validated by three experts. The pieces of information were not opinion survey and were not subjected to variation by individual respondents. Reliability test was therefore not considered necessary.

\section{RESUltS}

Rivers State schools are located both in Urban and Rural Areas; it was therefore, necessary to observe Urban and Rural schools presented for study at a glance on tables. 
Distribution of Direct Teaching Plants and Teaching Manpower Resources in Era of Economic Recession for Upper Basic Education in Rivers State, Nigeria

Research Question 1: How adequate is the distribution of direct teaching plants for public upper basic education delivery in urban and rural areas in Rivers State in this era of economic recession in Nigeria?

Table1: Status of distribution of direct teaching plants to upper basic schools in rural and urban areas

\begin{tabular}{|l|l|l|l|l|l|l|l|l|l|}
\hline \multirow{2}{*}{$\begin{array}{l}\text { S } \\
\mathbf{N}\end{array}$} & \multirow{2}{*}{$\begin{array}{l}\text { Racilities and Instructional } \\
\text { Resources }\end{array}$} & $\begin{array}{l}\text { Estimated } \\
\text { requirements }\end{array}$ & \multicolumn{2}{l|}{ Availability } & \multicolumn{2}{l|}{$\begin{array}{l}\text { Estimated } \\
\text { Shortfall }\end{array}$} & \multicolumn{2}{l|}{$\%$ shortfall } \\
\cline { 2 - 11 } & Urban & Rural & Urban & Rural & Urban & Rural & Urban & Rural \\
\hline 1 & Classroom spaces & 14345 & 22552 & 8098 & 16305 & 6247 & 12027 & 43.55 & 53.33 \\
\hline 2 & Classroom chairs/ Desks & 14345 & 22552 & 6853 & 15060 & 7492 & 13576 & 52.23 & 60.20 \\
\hline 3 & Library Space & 3586 & 5638 & 560 & 2612 & 3026 & 5044 & 84.38 & 89.47 \\
\hline 4 & $\begin{array}{l}\text { Number of library sitting space } \\
\text { with tables and chairs }\end{array}$ & 3586 & 5638 & 843 & 2895 & 2743 & 4666 & 76.50 & 82.76 \\
\hline 5 & Basic science laboratory space & 3586 & 5638 & 1121 & 3173 & 2465 & 4757 & 68.75 & 84.38 \\
\hline 6 & $\begin{array}{l}\text { Basic science laboratory } \\
\text { furniture/ equipment }\end{array}$ & 3586 & 5638 & 672 & 2724 & 2914 & 5187 & 81.25 & 92.00 \\
\hline 7 & Computer studio & 3586 & 5638 & 448 & 2500 & 3138 & 5439 & 87.50 & 96.47 \\
\hline 8 & $\begin{array}{l}\text { Functional computers in the } \\
\text { studio }\end{array}$ & 3586 & 5638 & 103 & 2155 & 3483 & 5607 & 97.14 & 99.45 \\
\hline 9 & Home economics laboratory & 3586 & 5638 & 448 & 2500 & 3138 & 5242 & 87.50 & 92.98 \\
\hline 10 & $\begin{array}{l}\text { Basic science \& technology } \\
\text { laboratory }\end{array}$ & 3586 & 5638 & 336 & 2388 & 3250 & 5341 & 90.63 & 94.74 \\
\hline 11 & Creative arts studio & 3586 & 5638 & 426 & 2478 & 3160 & 4451 & 88.13 & 78.95 \\
\hline 12 & Teachers' office spaces & 722 & 879 & 274 & 431 & 448 & 598 & 62.10 & 68.00 \\
\hline 13 & Teachers' tables & 722 & 879 & 495 & 652 & 227 & 556 & 31.40 & 63.21 \\
\hline 14 & Teachers' chairs & 722 & 879 & 331 & 488 & 391 & 634 & 54.21 & 72.11 \\
\hline & Aggregate mean & & & & & & & $\mathbf{7 1 . 8 1}$ & $\mathbf{8 0 . 5 8}$ \\
\hline
\end{tabular}

Note: 1 . Sampled urban Schools $=32 ;$ Student population $=14,345 ;$ Teachers $=879$.

\section{Sampled rural schools $=57 ;$ Student population $=22,552 ;$ Teachers $=722$}

The result in table(1) based on percentage shortfalls in the distribution of these facilities has clearly shown that there is high level of inadequacy in the distribution of all the facilities examined in both schools located in rural and urban areas for the 89 schools examined. This is because the percentage shortfall in the distribution of these school plants ranged between $31.40 \%$ and $97.14 \%$ in urban schools and between $53.33 \%$ and $99.45 \%$ in the rural located schools. This level of shortfall gives an aggregate mean of $71.81 \%$ in urban areas and $80.58 \%$ in rural areas. This indicated that there are serious shortfalls in school plant distribution in both urban and rural areas, but the situation is serious in rural schools (see the aggregate mean percentage shortfall in Table (1). The disparity between rural and urban areas in the level of inadequacy in the distribution of direct teaching school plants is more glaring when the facts were given graphical presentation as shown in figure (1).

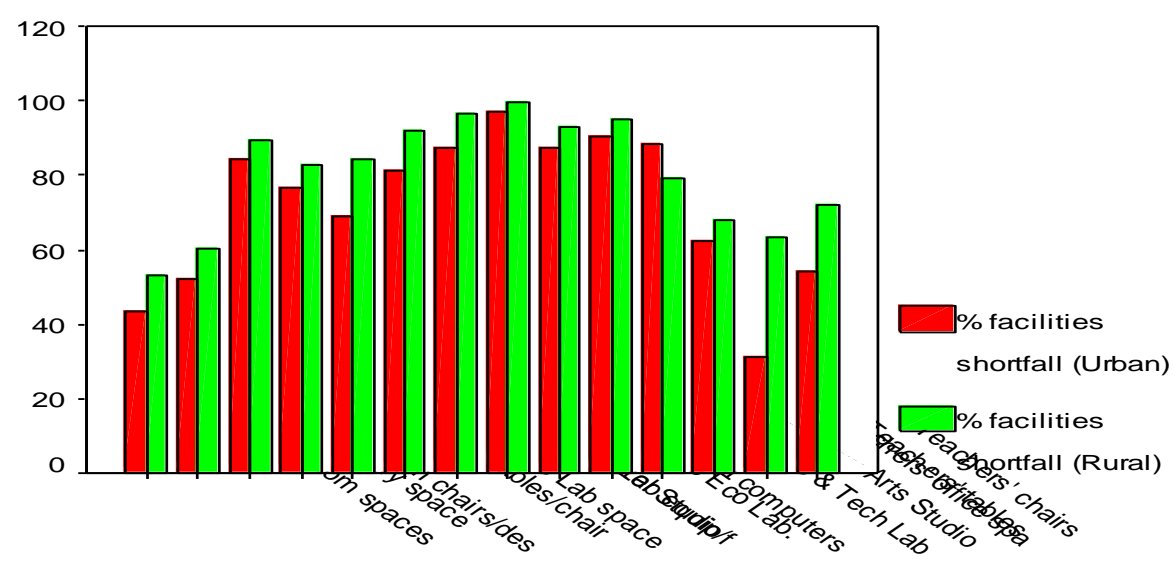

Facilities

Figure1: Mean \% of school facilities shortfall in urban and rural areas 
As graphically represented, it is obvious that for each of the facilities for which shortfalls are computed, the percentage shortfalls for rural schools are all higher than those of urban schools. It is clearly evident that the distribution of direct teaching plants is grossly inadequate in both rural and urban schools, but the situation was more serious for schools located in rural areas.
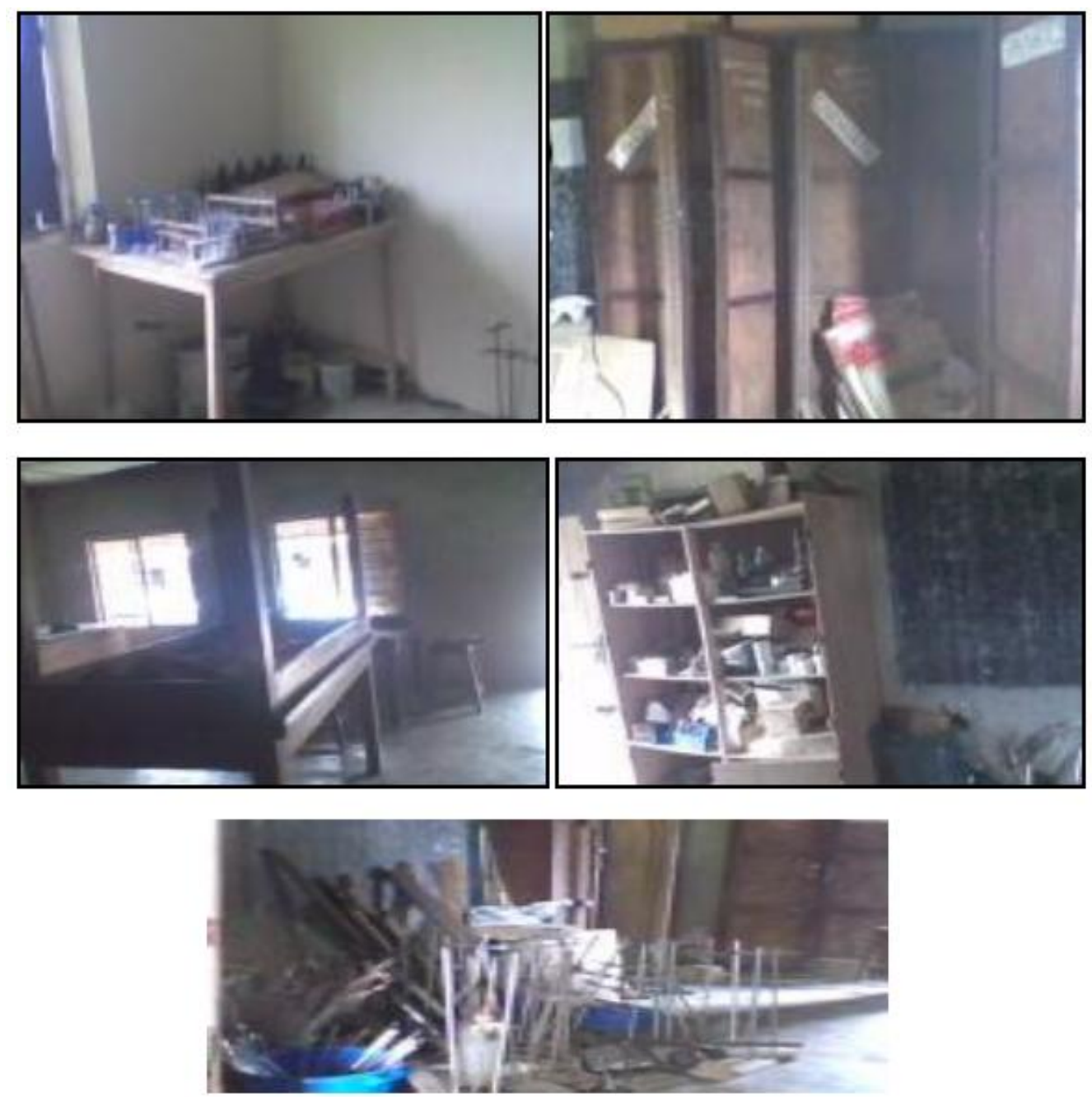

Poorly furnished science laboratory

Figure2: Photo clip on Status of science laboratory \& equipment

The construction of model Mega-Junior Secondary Schools to enhance equitable distribution of the plants since 2013 in the state, attracted the researcher's attention. Currently published information (Rivers State Ministry of Education(2013-2017) revealed that eight (8) out of the twelve (12) sampled Local Government Areas, where the development of such schools started, only one has been completed and put into use with a capacity of seven hundred (700) children [see table (2)].

Table2: Mega model Junior Secondary School (upper basic) of International Standard

\begin{tabular}{|l|l|l|l|l|l|}
\hline Local Govt. & $\begin{array}{l}\text { School } \\
\text { Location. }\end{array}$ & $\begin{array}{l}\text { Dev. } \\
\text { Level }\end{array}$ & $\begin{array}{l}\text { Functional } \\
\text { Level }\end{array}$ & $\begin{array}{l}\text { Projected } \\
\text { Capacity }\end{array}$ & $\begin{array}{l}\text { Present } \\
\text { Capacity }\end{array}$ \\
\hline Eleme & Ebubu & Completed & In use & 1000 & 700 \\
\hline Tai & Kira & $95 \%$ & Not in use & 1000 & 700 \\
\hline Etche & Okehi & $95 \%$ & Not in use & 1000 & 700 \\
\hline Omuma & Omuma & $80 \%$ & Not in use & 1000 & 700 \\
\hline Emuoha & Emuoha & $80 \%$ & Not in use & 1000 & 700 \\
\hline Asari- Turi & Buguma & $80 \%$ & Not in use & 1000 & 700 \\
\hline Oyigbo & Oyigbo & $30 \%$ & Not in use & 1000 & 700 \\
\hline Andoni & Ngo & $30 \%$ & Not in use & 1000 & 700 \\
\hline
\end{tabular}

Source: Rivers State Ministry of Education: Working towards a more educated citizenry (2013-2017). 
As clearly shown in the table, the remaining seven (7) schools are at different levels of completion. At completion, these ones would not guaranteed adequate secondary school places and facilities for the teaming population. The graphical presentation of the levels of completion of these Mega-Model Schools projects, are shown in figure (3).

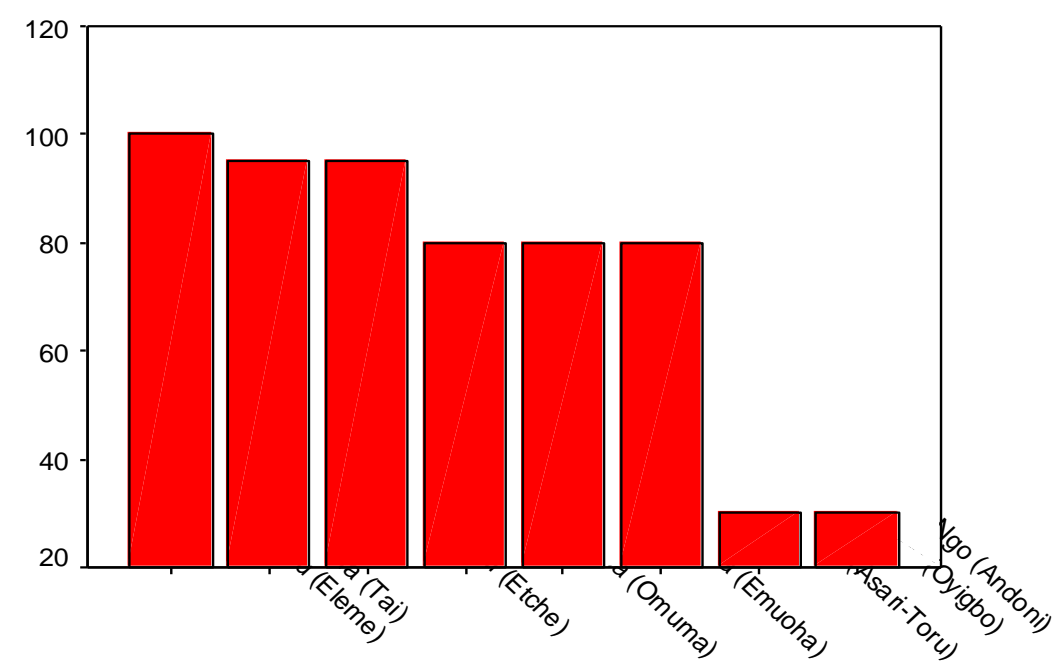

School Location (LGA)

Figure3: Locations and percentage level of completion of Mega-Model Secondary Schools in Rivers State.

Research Question 2: What are the conditions of direct teaching plants distributed for public upper basic education delivery in urban and rural areas of Rivers State?

The condition of available facilities in terms of whether they are in usable form or not were also assessed. The percentage of facilities in good condition was determined and used to address this research question. The result of the data analysis was presented in table (3) for the 14 facilities.

Table3: Condition of direct teaching plants in schools in rural and urban areas

\begin{tabular}{|c|c|c|c|c|c|c|c|}
\hline \multirow[t]{2}{*}{$\begin{array}{l}\mathbf{S} \\
\mathbf{N}\end{array}$} & \multirow[t]{2}{*}{$\begin{array}{l}\text { Facilities and Instructional } \\
\text { Resources }\end{array}$} & \multicolumn{2}{|c|}{ Available facilities } & \multicolumn{2}{|c|}{$\begin{array}{l}\text { Facilities in good } \\
\text { condition }\end{array}$} & \multicolumn{2}{|c|}{$\begin{array}{l}\% \text { of facilities in } \\
\text { good condition }\end{array}$} \\
\hline & & Urban & Rural & Urban & Rural & Urban & Rural \\
\hline 1 & Classroom spaces & 8098 & 16305 & 5443 & 8824 & 67.22 & 54.12 \\
\hline 2 & Classroom chairs/ Desks & 6853 & 15060 & 4401 & 7197 & 64.22 & 47.78 \\
\hline 3 & Library Space & 560 & 2612 & 309 & 1102 & 55.1 & 42.20 \\
\hline 4 & $\begin{array}{l}\text { Number of library sitting space } \\
\text { with tables and chairs }\end{array}$ & 843 & 2895 & 574 & 1509 & 68.11 & 52.11 \\
\hline 5 & Basic science laboratory space & 1121 & 3173 & 764 & 1587 & 68.11 & 50.01 \\
\hline 6 & $\begin{array}{l}\text { Basic science laboratory } \\
\text { furniture/ equipment }\end{array}$ & 672 & 2724 & 297 & 1095 & 44.23 & 40.21 \\
\hline 7 & Computer studio & 448 & 2500 & 185 & 1006 & 41.20 & 40.23 \\
\hline 8 & $\begin{array}{l}\text { Functional computers in the } \\
\text { studio }\end{array}$ & 103 & 2155 & 50 & 718 & 48.22 & 33.33 \\
\hline 9 & Home economics laboratory & 448 & 2500 & 252 & 1081 & 56.22 & 43.25 \\
\hline 10 & $\begin{array}{l}\text { Basic science \& technology } \\
\text { laboratory }\end{array}$ & 336 & 2388 & 184 & 1008 & 54.64 & 42.22 \\
\hline 11 & Creative arts studio & 426 & 2478 & 193 & 1048 & 45.28 & 42.29 \\
\hline 12 & Teachers' office spaces & 274 & 431 & 155 & 193 & 56.74 & 44.71 \\
\hline 13 & Teachers' tables & 495 & 652 & 337 & 333 & 68.12 & 51.01 \\
\hline 14 & Teachers' chairs & 331 & 488 & 216 & 295 & 65.12 & 60.47 \\
\hline & Aggregate mean & & & & & 57.32 & 46.00 \\
\hline
\end{tabular}

Note: 1 . Sampled urban Schools $=32 ;$ Student population $=14,345 ;$ Teachers $=879$. 
Distribution of Direct Teaching Plants and Teaching Manpower Resources in Era of Economic Recession for Upper Basic Education in Rivers State, Nigeria

2. Sampled rural schools $=57 ;$ Student population $=22,552 ;$ Teachers $=722$

The result in Table (3) reveals that the percentage of facilities in good condition ranges between $41.20 \%$ and $68.12 \%$ for schools in urban areas and $33.33 \%$ and $60.47 \%$ for schools in rural areas (see the $\%$ of facilities in good condition in table 3 ). This shows an aggregate mean percentage of facilities in good condition of $57.32 \%$ for urban areas and $46.00 \%$ for rural areas. Judging by these percentages of facilities in good condition in table (3), it becomes clear that moderate levels of available facilities were in good (functional) condition in urban areas, while low percentage levels of these facilities in good condition in rural areas.

The sample photo clips taken by the researcher in the course of the survey as presented in figures 4 and 5 on the status of classrooms, furniture and laboratories clearly confirm the facts demonstrated by the result in table 3

As can be seen in the sample photo clips, the classroom spaces, furniture as well as the laboratories in most schools were not only dilapidated but poorly furnished. All these clearly show that available direct teaching plants were moderately in good condition in urban areas but in poor condition in rural areas.

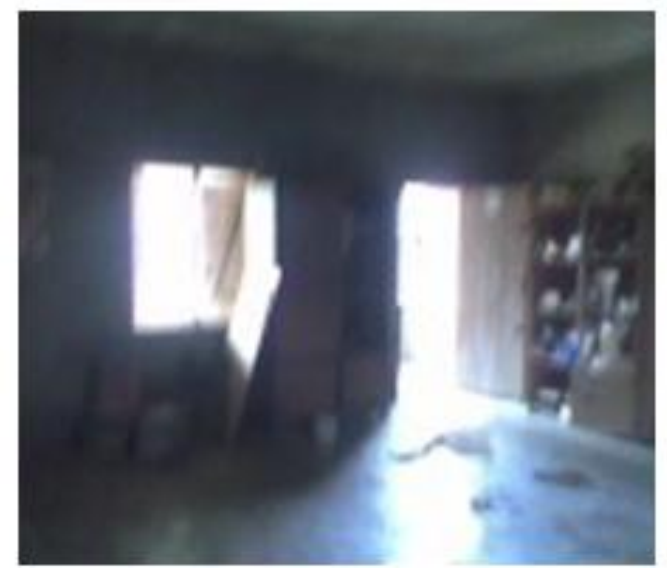

Broken walls into classrooms

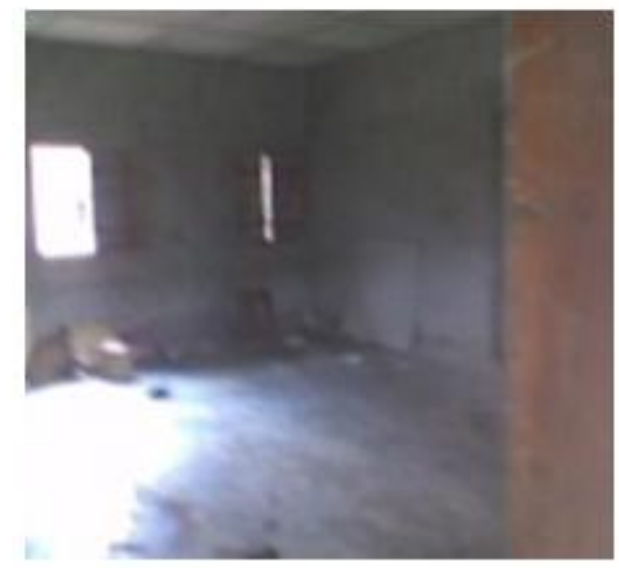

Broken walls into science laboratory

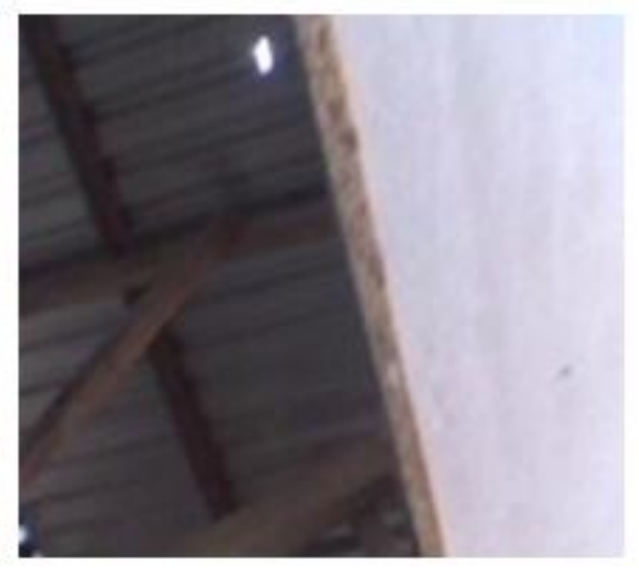

Dilapidated roof classroom building in use

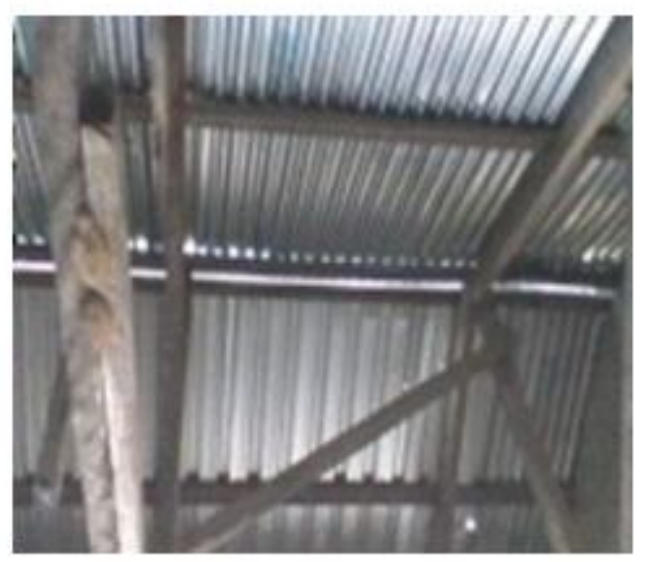

Partially de-roofed staffroom in use

Figure4: Photo clips on the status of classrooms, furniture and staffrooms

The disparity between schools in urban and rural areas in the condition of available facilities is e clarified the graphical presentation in figure.5.

As clearly shown in the figure, the percentages of facilities in good condition in urban areas are all higher than the percentages of facilities in good condition in rural areas for all the 14 direct teaching plants examined. The gaps are widest for classroom space/furniture, library facilities and teachers' offices, tables and chairs (see the gaps between the two bars for these facilities in Figure (5). 


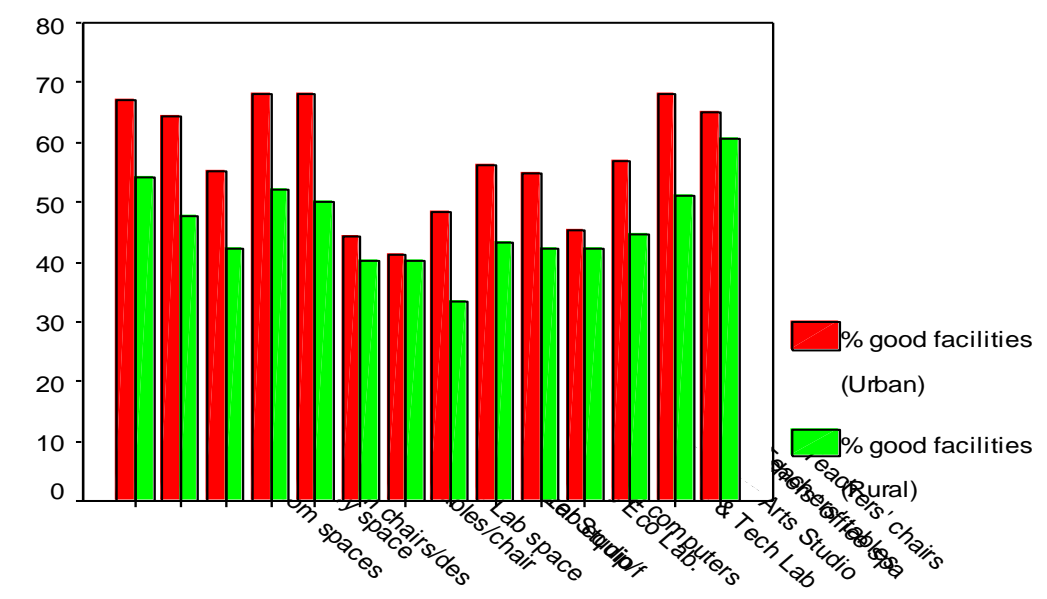

Facilities

Figure5: Mean \% of school facilities in good condition in urban and rural areas

Research Question 3: How adequate are the distributions of teaching manpower resources for public upper basic education delivery in urban and rural areas in Rivers State?

The adequacy of teaching manpower resources was examined using the ratio of pupils to a teacher by subject, to judge against the minimum standard of 35 children to a teacher in the junior secondary school level as specified by government policy (FME, 2004). The result of this data analysis was shown in table 4 for schools in both urban and rural areas.

Table4: Mean ratio of pupils to a teacher by subjects in schools in rural and urban areas

\begin{tabular}{|c|c|c|c|c|c|c|}
\hline & \multirow[t]{2}{*}{ Subjects } & \multicolumn{2}{|c|}{ Teachers by subjects } & \multicolumn{2}{|c|}{ Ratio of pupils to a teacher } & \multirow[t]{2}{*}{ Mean set ratio } \\
\hline & & Urban & Rural & Urban & Rural & \\
\hline 1 & Mathematics & 97 & 82 & 149 & 278 & 214 \\
\hline 2 & English & 109 & 99 & 132 & 228 & 180 \\
\hline 3 & Integrated Science & 85 & 73 & 169 & 309 & 239 \\
\hline 4 & Social Studies & 168 & 135 & 86 & 170 & 128 \\
\hline 5 & Computer Studies & 55 & 47 & 261 & 480 & 371 \\
\hline 6 & Introductory Technology & 30 & 56 & 478 & 396 & 437 \\
\hline 7 & Home Economics & 59 & 47 & 243 & 480 & 362 \\
\hline 8 & Business Studies & 64 & 56 & 224 & 403 & 314 \\
\hline 9 & French & 48 & - & 299 & & \\
\hline 10 & Civic Education & 38 & 14 & 378 & 1611 & 995 \\
\hline 11 & Cultural and Creative Arts & 21 & 36 & 683 & 626 & 655 \\
\hline 12 & $\begin{array}{lll}\begin{array}{l}\text { Physical } \\
\text { Education }\end{array} & \& & \text { Health } \\
\end{array}$ & 40 & 35 & 359 & 663 & 511 \\
\hline 13 & Agricultural Science & 44 & 31 & 334 & 727 & 531 \\
\hline 14 & Christian Religious Studies & 24 & 14 & 598 & 1611 & 1105 \\
\hline 15 & Islamic Studies & - & - & & & \\
\hline 16 & Hausa & - & - & & & \\
\hline 17 & Igbo Language & - & - & & & \\
\hline 18 & Yoruba Language & - & - & & & \\
\hline & Aggregate Mean & & & 314 & 570 & 442 \\
\hline
\end{tabular}

Note: 1 . Sampled urban Schools $=32 ;$ Student population $=22,552 ;$ Teachers $=879$.

2. Sampled rural schools $=56 ;$ Student population $=14,345 ;$ Teachers $=722$

As revealed by the ratios in table 4, there exists, serious inadequacies of teacher distribution in all the subject areas in both urban and rural areas. This is because the ratios in table 4 were all far in excess of the maximum stipulation of 35 . The least ratio as can be seen in the table was 86 for social studies in urban areas and 170 for the same social studies in rural areas, while the maximum of 683 for 
Distribution of Direct Teaching Plants and Teaching Manpower Resources in Era of Economic Recession for Upper Basic Education in Rivers State, Nigeria

Creative Arts in Urban areas and 1611 for Christian Religious Studies and Civic Education in rural areas. There are no teachers at all for Islamic Studies, Hausa, Igbo and Yoruba (see blank spaces for these subjects in table 4.It is clearly observable from the table that the ratios were consistently higher in rural area for all the subjects, with an aggregate mean of 314 for urban areas and 570 for rural areas, with an aggregate mean set of 442 . This difference between rural and urban areas in the ratio of pupils to a teacher is clarified by the graphical presentation in figure 6 .

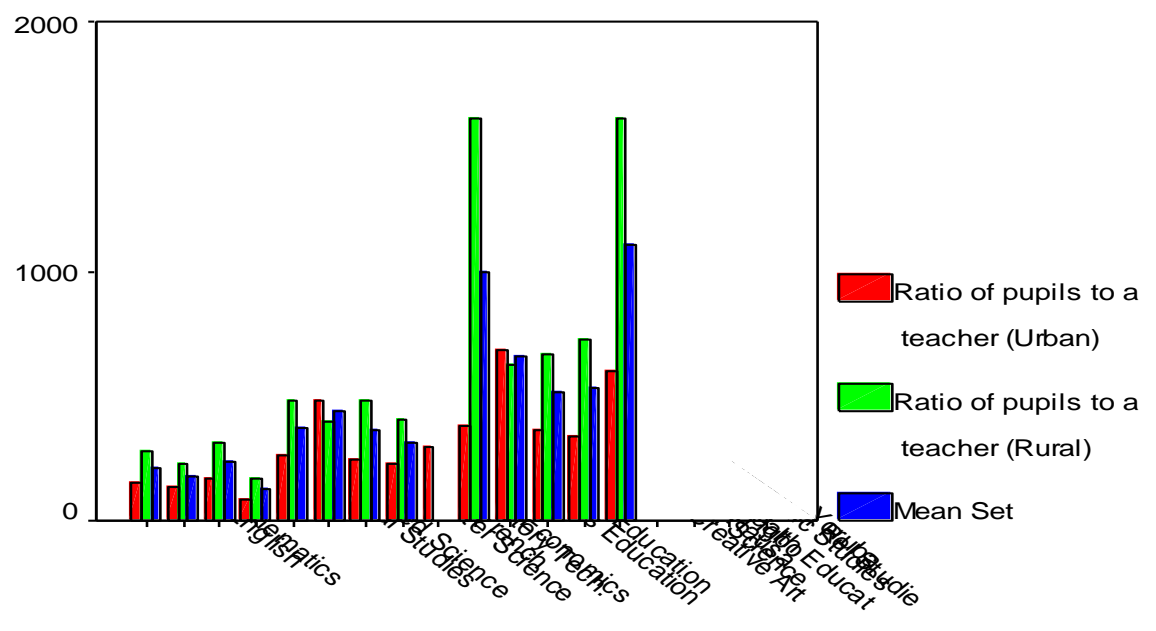

Subjects

Figure6: Mean ratio of pupils to a teacher by subjects in urban and rural areas

As clearly shown in the figure, the bars representing ratio of pupils to a teacher are higher for all the subjects for schools located in rural areas when compared to the rural areas, indicating that teaching manpower inadequacy was more pronounced in rural areas.

Research question 4: What is the quality of teaching manpower resources for public junior secondary delivery in urban and rural areas in Rivers State?

The quality of teaching manpower resources available to public upper basic schools was also examined, using percentage of professional teachers in teaching and the length of teaching experience of the teachers. The result of the data analysis is presented in table 5 .

Table5: Percentage of professional teachers by subjects in schools in rural and urban areas

\begin{tabular}{|c|c|c|c|c|c|c|c|}
\hline & Subjects & Total T & chers & Profess & Teachers & $\%$ of pr & al teachers \\
\hline & & Urban & Rural & Urban & Rural & Urban & Rural \\
\hline 1 & Mathematics & 97 & 82 & 67 & 55 & 70.22 & 68.17 \\
\hline 2 & English & 109 & 99 & 86 & 66 & 79.29 & 66.69 \\
\hline 3 & Integrated Science & 85 & 73 & 58 & 45 & 68.55 & 62.23 \\
\hline 4 & Social Studies & 168 & 135 & 125 & 89 & 74.67 & 66.71 \\
\hline 5 & Computer Studies & 55 & 47 & 35 & 22 & 62.78 & 45.77 \\
\hline 6 & Introductory Technology & 30 & 56 & 22 & 36 & 71.87 & 62.71 \\
\hline 7 & Home Economics & 59 & 47 & 46 & 31 & 77.99 & 66.32 \\
\hline 8 & Business Studies & 64 & 56 & 50 & 43 & 77.50 & 77.65 \\
\hline 9 & French & 48 & - & 28 &. & 57.41 & - \\
\hline 10 & Civic Education & 38 & 14 & 29 & 8 & 76.00 & 55.77 \\
\hline 11 & Cultural and Creative Arts & 21 & 36 & 20 & 31 & 96.00 & 85.00 \\
\hline 12 & Physical \& Health Education & 40 & 35 & 34 & 26 & 84.11 & 75.83 \\
\hline 13 & Agricultural Science & 44 & 31 & 40 & 23 & 92.02 & 75.00 \\
\hline 14 & Christian Religious Studies & 24 & 14 & 22 & 8 & 91.11 & 55.79 \\
\hline 15 & Islamic Studies & - & - & & & & \\
\hline 16 & Hausa & - & - & & & & \\
\hline 17 & Igbo Language & - & - & & & & \\
\hline 18 & Yoruba Language & - & - & & & & \\
\hline & Aggregate Mean & & & & & 78.62 & 66.43 \\
\hline
\end{tabular}


The result in table 5 revealed that the percentage of professionally trained and qualified teachers in each of the school subjects is moderately high (see aggregate mean of $78.62 \%$ for urban schools and $66.43 \%$ for rural schools). It is highest for subjects like creative arts, physical and health education, agricultural science and physical and Christian religious studies (see the mean percentage of these subjects in table 5). The percentage is generally higher for schools in urban areas when compared to those in rural areas. This can be confirmed with the graphical presentation of the data in figure7.

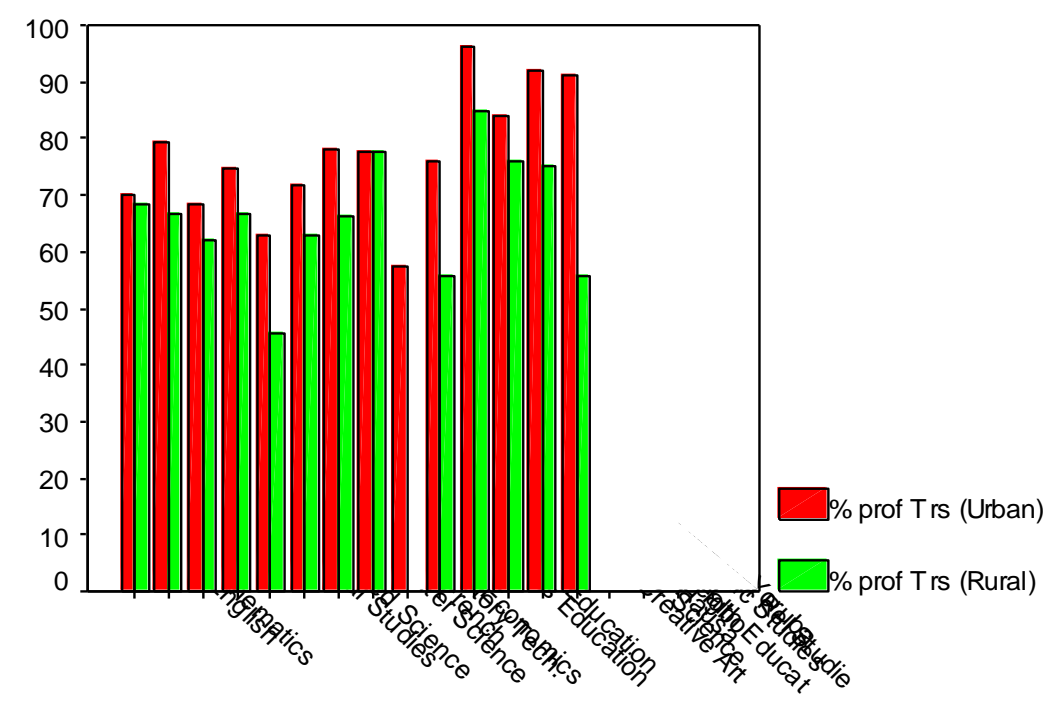

Subjects

Figure7: Mean \% of professionally trained teachers in urban and rural areas

As can be seen from the graphical presentation in figure 7, the bars representing the proportion of professionally trained and qualified teachers is higher for all the subjects examined. Judging by this variable, the quality of teachers is higher in urban areas. The second variable which the researcher used in judging the quality of teachers is the average length of teaching experience of the teachers and the result of data analysis on this shown in table 6 .

Table6: Average teaching experience of teachers by subjects in Urban and Rural areas

\begin{tabular}{|l|l|l|l|l|}
\hline SN & \multirow{2}{*}{ Subjects } & Mean Teaching experience (in years) & \multirow{2}{*}{ Mean set } \\
\cline { 3 - 4 } & & Urban & Rural & \\
\hline 1 & Mathematics & 26.50 & 16.57 & 21.54 \\
\hline 2 & English & 27.17 & 22.41 & 24.79 \\
\hline 3 & Integrated Science & 17.45 & 15.55 & 16.50 \\
\hline 4 & Social Studies & 21.47 & 20.14 & 20.81 \\
\hline 5 & Computer Studies & 3.73 & 3.27 & 3.50 \\
\hline 6 & Introductory Technology & 3.47 & 2.88 & 3.18 \\
\hline 7 & Home Economics & 16.22 & 14.14 & 15.18 \\
\hline 8 & Business Studies & 11.42 & 12.44 & 11.93 \\
\hline 9 & Frenchs & 9.17 & 7.24 & 8.21 \\
\hline 10 & Civic Education & 22.18 & 17.55 & 19.77 \\
\hline 11 & Cultural and Creative Arts & 23.36 & 20.23 & 21.80 \\
\hline 12 & Physical \& Health Education & 19.22 & 17.47 & 18.35 \\
\hline 13 & Agricultural Science & 17.18 & 9.11 & 13.15 \\
\hline 14 & Christian Religious Studies & 22.55 & 20.18 & 21.37 \\
\hline 15 & Islamic Studies & - & - & - \\
\hline 16 & Hausa & - & - & - \\
\hline 17 & Igbo Language & - & - & - \\
\hline 18 & Yoruba Language & - & - & - \\
\hline & Aggregate Mean & $\mathbf{1 7 . 2 2}$ & $\mathbf{1 4 . 2 3}$ & $\mathbf{1 5 . 7 3}$ \\
\hline
\end{tabular}


The evidence in table 6 shows that the teaching experience of urban school teachers ranged between 7.28 years and 27.17 years with an aggregate mean of 17.22 years. On the other hand, the teaching experience of teachers in the rural areas ranged between 3.27 years and 22.41 years, with an aggregate mean of 14.23 years. The mean set for experience for all the teachers ranged between 3.50 and 24.79, with an aggregate mean of 15.73. Going by this, it is correct to say that teachers in both urban and rural areas are well experienced in teaching, even though teachers in urban areas are generally more experienced in teaching than those in rural areas. This can be confirmed from the graphical presentation in figure 7.

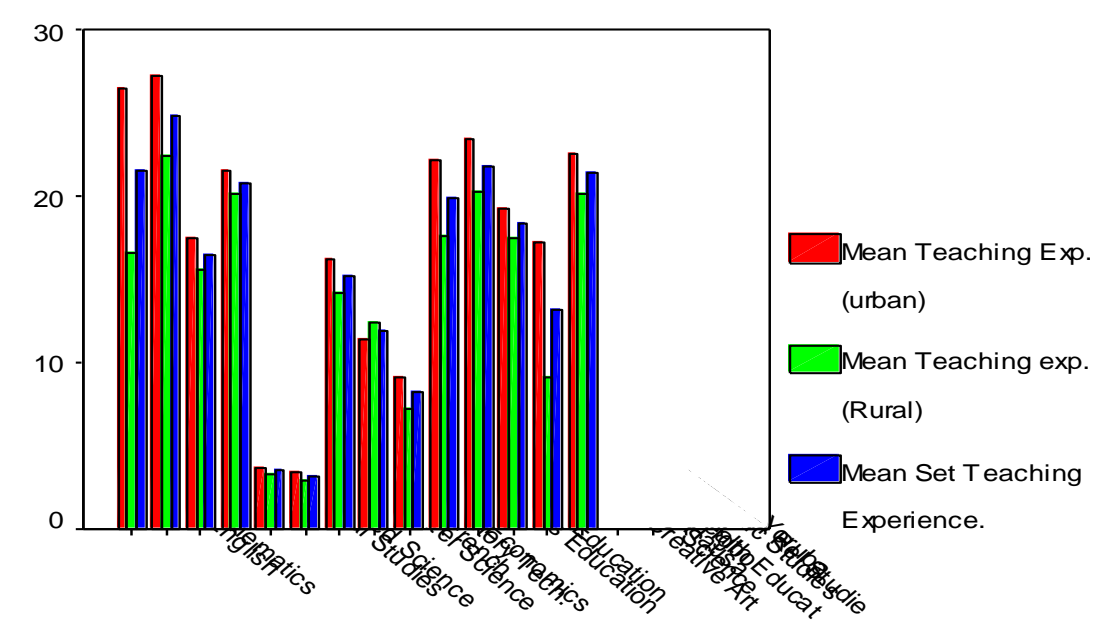

Subjects

Figure7: Mean years of teaching experience of teachers in urban and rural areas

As clearly shown, the bars representing length of teaching experience of urban school teachers are all higher than those representing the length of teaching experience of teachers in rural areas for all the teaching subjects examined, except for subjects like Hausa, Yoruba, Igbo and Islamic Studies that have no teachers at all.

From the analysis using the two quality variables, it is clear that there are reasonably high quality teachers in the public school system, judging by the proportion of those who are professionally trained and qualified and their length of teaching experience. This is applicable to school in both urban and rural areas, even though there are relatively better quality teachers in the urban areas than the rural areas.

\section{DISCUSSION OF FINDINGS}

The result showed that there are serious shortfalls in school plant distribution in both urban and rural areas, but the situation is more serious in rural schools for all the facilities. This evidence appears to be supported by many scholars reviewed in this study like Charles, Obiora and Omekwu (2006), Nwaeke (2006) and Okeke (2007). To these scholars, facilities in public schools in Nigeria since then were generally inadequate, beside the fact that their conditions are deplorable due to use and wares made it worst in economic recession. This evidence is not so surprising, as many interest groups have been talking on the poor state of these facilities. However, one had expected that the intervention effort by the state government to build model schools should have addressed this issue. Unfortunately, the number of model schools available is too few compared to the total number of schools in the state.

The study also discovered that the condition of available facilities in schools is not very encouraging. Specifically, the study revealed that moderate percentages of available facilities are in good condition in urban areas, while low percentages of school facilities in rural areas are in good condition. This evidence is confirmed by Marinoho (2009) who decried that Schools in Nigeria have four major problems which are broken walls and roof of the classrooms, lack of libraries, books lacking local content and obsolete laboratories equipment. Like the issue of facilities adequacy, the condition of available school facilities in public schools has been poor for quite some times. The evidence is the 
fact that many parents before now preferred to send their children to private instead of public schools. This happens when available school facilities are over utilized because of inadequacy. Therefore, it is an issue that cannot be solved in isolation now that the population of public schools has started to increase as parents are withdrawing their children from private to public schools to avert the influence of economic recession on the education of their children. Inadequate distribution of these facilities generates quicker decay of available ones as a result of over usage (use and wares)

On the teaching manpower adequacy, the researcher found that there are high levels of inadequacy in the distribution of teachers in all the subject areas. It is worst for subjects like computer science, home economics, French, civic education, cultural and creative arts, physical and health education, agric science and Christian religious studies. This inadequacy in teacher distribution was found to be more serious for urban schools, when compared to rural schools. If resources for teaching are inadequate, teacher distribution has been found to be more inadequate. This could be due to the fact that for quite some time, no comprehensive recruitment has been done for teachers, even when the introduction of the UBE programme was expected to increase enrolment in public schools. It is possibly for this reason that the state ministry of education in collaboration with the UBE Board sometimes planned mass recruitment of teachers for the public school system now suspended by the influence of economic recession.

The study discovered that schools in both urban and rural areas have reasonably high quality teachers, judging by the percentage of those that are professionally, trained and by their length of teaching experience. The quality of teachers is however relatively better in urban areas, when compared with schools located in rural areas, judging by both professional qualification and length of teaching experience .Since teaching has been professionalized, recruiting non-professional teachers is no longer permitted. Why we still have reasonable percentage of professionally untrained teachers is because there are still some old teachers that have not complied with directive to upgrade their professional status.

\section{CONCLUSION}

From the findings of this study as discussed above, it is clear that the , distribution of direct teaching plants and teaching manpower resources in public schools is not adequate to guarantee quality upper basic educational programme. The provision of this level of education presently would be grossly deficient in terms of achieving qualitative education delivery as the experienced teachers are retiring, no corresponding recruitments of qualified teachers and the persisting economic recession.

\section{RECOMMENDATIONS}

Based on the result of this study as presented, the following recommendations are made:

1. The Ministry of Education in collaboration with the UBE Board should establish and equip educational resource centres for facilities that government cannot afford to provide for all schools because of cost implication so that they can be centrally used by group of schools in the same locality. This will improve students' access to these facilities at lower cost thereby assisting overcoming the bane effects of economic recession on the distribution of these plants.

2. Equally, the UBE Board in collaboration with the school management should establish facilities maintenance workshops, which should be adequately supported with adequate budget and trained personnel to regularly carry out facilities maintenance. This will ensure that school facilities available have longer life span.

3. Staff and students should be given adequate orientation on facilities handling to minimise frequent break down of school plants associated with poor handling and usage.

4. Need-based recruitment of professionally trained and qualified teachers should be carried out and the teachers so recruited should be distributed, to both schools in urban and rural areas based on the staffing needs of individual schools.

\section{REFERENCES}

[1] Adesina, D (2013, May15) "Where are the Teachers? Guardian. Lagos, Nigeria; (P 14)

[2] All Nigerian Principals of Secondary Schools (2002), Report of Pilot Study on Factors for Quality Education in Lagos State Secondary Schools, Lagos 
Distribution of Direct Teaching Plants and Teaching Manpower Resources in Era of Economic Recession for Upper Basic Education in Rivers State, Nigeria

[3] Agabi,O.G. (2006), Educational Planning in International Perspective, Lecture Manuscript, ,Department of Education management, University of Port Harcourt.

[4] Babalola, J. (2000) Fundamentals of Economic Of Educational Ibadan, Department of Educational Management, University of Ibadan Nigeria.

[5] Collaborative Research Institution and service Delivery (2009), Institution and Service delivery Research, Nairobi, Kenya; Institution and Services. African Economic Research, From http:/www.aercafrica.org/ programmes/research-collab.

[6] Duncan .W, (2017 April), The Wiley Handbook of Diversity in Special Education, Netherland

[7] Ebong, J.M (2008), Understanding Economics of Education, Port Harcourt, Eagle Lithegraph Press

[8] Emeka, U.(2009), “10 Years of Civil Rule,” Government Lacks Sincerity of Purpose in Policy Making Implementation, The Nation, Lagos, Vintage Press(3)1040, From, http:/www.thenation/onlineng.net

[9] Emetarom,U.G (1991), Resourcing in Educational Planning in Ewazurike (ed) Educational Panning and National Development: A Nigerian perspective, Owerri; Klet Ken Publisher "10 Years of Civil Rule”, Government lacks Sincerity of Purpose in Policy Making Implementation”.

[10] Federal Government of Nigeria (2004), National Policy on Education, Lagos: NERDC.

[11] Federal Government of Nigeria (2004), Compulsory Free Universal Basic Education act, Lagos, Federal government Press

[12] Igbudu, J.N; \& Ipalibo, W.B (2017), Managing Secondary Education in the era of Economic Recession in Nigeria, African Journal of Educational Research and Development (AJERD; University of Port Harcourt, (.9)1.

[13] Kelsall, R. K, Hellen .M, Kelsall (2016), The School Teacher in England and United State Edmund King Press, @www.books. google.com.ng.

[14] Maduagwu, S.N. \& Nwogu U.J. (2006), Resource Allocation and Management, Port Harcourt, Rivers State Printing Press, Obio/Akpor L.G.A.

[15] Marinho, T. (2009 April1). Yet another Education Meeting "The Nation; Lagos: Vintage Press Limited, Wednesday April 1:2009 vol. 3 No.0985 views@thenationlineng.com.

[16] National Academies, (2006), Adviser to the Nation on Science Engineering and Medicine, Washington D.C: The National Academic Press.

[17] Nwa for, S.O. (2006), "Successful Implementation of the Universal Basic Education Programme in Multicultural Society, Implications for Educational Planning.

[18] .Nwaeke, G.C. (2006), The Demand and Supply of Educational Resources in Rivers State's Secondary School, Unpublished Ph.D Dissertation, Department of Educational Management; University of Port Harcourt, Rivers State, Nigeria.

[19] Nwinee, F. B.(2017),Economic Recession in Nigeria: Esau's Syndrome and Irrational Legislative Exuberance Inaugural Lecture Series NO.140

[20] Ohale, L. (2018), Porverty in the Midst of Plenty: The Paradox of Nigeria's Development, Inaugural Lecture Series NO.145,

[21] .Okeke, B.S, Mosiri C.P, Elele, S.O. Ozurumba, M.M \& Igwe S.O. (1985). A Hand Book in Educational Administration; Owerri: New Africa Publishing Company.

[22] Rivers State Ministry of Education (2017), Working Towards a More Educated Citizenry, Port -Harcourt, Rivers State, Possibilities' Printing Press

[23] THISDAY Newspaper,(2017 March 2), "Court Upholds Right of Nigerian Children to Free Primary Education”, Abuja, Nigeria From, hello @ thisdaylive.com.( March 2, 2017)

Citation: Dr. Agabi, G. O, Dr. Ukaigwe, P.C. "Distribution of Direct Teaching Plants and Teaching Manpower Resources in Era of Economic Recession for Upper Basic Education in Rivers State, Nigeria. "International Journal of Humanities Social Sciences and Education (IJHSSE), vol 5, no. 8, $2018, \mathrm{pp}$. 99-111. doi: http://dx.doi.org/10.20431/2349-0381.0508012.

Copyright: (c) 2018 Authors. This is an open-access article distributed under the terms of the Creative Commons Attribution License, which permits unrestricted use, distribution, and reproduction in any medium, provided the original author and source are credited. 